\title{
Psychosocial Skills Training for Social Innovation: Analysis of Three Programs for Different Stages of Development of Social Innovators
}

\author{
Mariana Bargsted \\ Organizational Psychology Department, Adolfo Ibáñez University, Avda. Diagonal las Torres 2640, CP. 7941169, \\ Santiago, Chile \\ Email: mariana.bargsted@uai.cl
}

\begin{abstract}
Social Innovation, as planned behavior, can be developed from specific training programs. The aim of this study was to determine the distinctive profiles of social innovators in three phases and to establish the basic training objectives for each stage. Three groups of participants answered a questionnaire: a) teenager enrolled in a one-year program of leadership training, b) students of a university course on social entrepreneurship and innovation, and c) social innovators applying for competitive funds. Differences among the three groups were identified in terms of values, motives, attitudes and social entrepreneurship intention. With this information, a series of guidelines are proposed in order to develop the competences and skills required at each stage.
\end{abstract}

Keywords: Psychosocial Skills, social innovation.

\section{Introduction}

Social innovation and social entrepreneurship are object, already, of public policies, especially regarding stimulation, education and follow-up of both social entrepreneurs and social entrepreneurship initiatives. Among the many faces that this phenomenon has, it is relevant to focus on the understanding of social entrepreneurship and innovation as a particular type of helping behavior that crosses the entrepreneur's career path. Such an approach carries, at least, two implications: on the one hand, social entrepreneurship and innovation is a complex behavior; and on the other hand, it implies a development process of motivations, attitudes, skills and competences to design, plan, implement and maintain a project with social impact. It means that, in one's personal trajectory, entrepreneurship and helping intentions are combined in a planned behavior.

Therefore, in order to study social entrepreneurship development, it is important to define it first. Social entrepreneurship is understood as an endeavor that "... encompasses the activities and processes undertaken to discover, define, and exploit opportunities in order to enhance social value by creating new ventures or managing existing organizations in an innovative manner" (Zahra, Gedajlovic, Neubaum, \& Shulman, 2009, p. 522). It includes all kinds of projects geared towards adding social value, improving quality of life and reducing social problems. Although many definitions of social entrepreneurship exist (Bacq \& Janssen, 2011) there is evidence of certain convergence regarding the fact that social entrepreneurship can have multiple shapes, all oriented to develop new projects, services or products in which both social and economic impacts are involved. Mair and Martí (2006) offered a working definition that alludes to "...a process involving the innovative use and combination of resources to pursue opportunities to catalyze social change and/or address social needs" (p.37).

As Dacin, Dancin and Matear (2010) stated, there is a considerable potential to better understand social entrepreneurship if we apply the theoretical and empirical insights achieved by the study of entrepreneurship from different perspectives, since social and traditional entrepreneurship share some common aspects. From this angle, social entrepreneurship can also be conceptualized as a career pattern related to a social vocation (Bargsted, Picón, Salazar, \& Rojas, 2013), as social entrepreneurs articulate both personal and professional projects in a sustained endeavor that could be a long-term entrepreneurship. This understanding of social entrepreneurship builds upon the definition of career as the totality of roles, positions and activities related to work in which a person can be engaged in 
(Arnold, 2001), which include all kinds of volunteering, paid jobs, occasional jobs, entrepreneurship, educational activities and home duties (Greenhaus, Callanan, \& Godshalk, 2010).

Thus, the work trajectory leads to the development of a stable career path that affects several decisions and behaviors called career identity, which includes personal aspirations and personal interests. Career identity builds on success and failure experiences and on the developed self-confidence. It becomes a part of the central self-concept due to its connection with a) self-perceived skills, abilities, and talent; b) needs and motives; and c) values and attitudes (Schein, 1996). Therefore, a career orientation to social entrepreneurship and innovation can be developed as a consequence of a number of experiences which stimulate certain values, motives, attitudes and self-perceived skills, thus shaping the entrepreneur's profile.

In light of the above findings, it can be useful to analyze the changes in the psychosocial profile of social entrepreneurs whilst they are involved in different formative activities. To this end, it is necessary to identify formal spaces where potential and actual social entrepreneurs receive different tools to improve their projects and developing innovations. These resources, however, are usually project rather than skill oriented, neglecting the development of the skills, strategies, and personal competences that social entrepreneurs require to be successful. Consequently, it is fundamental to gain greater insight into the psychosocial characteristics of social entrepreneurs that must be developed at different formation stages, in order to accurately plan an itinerary of the development and to evaluate the progress. Having identified three different stages of formal stimulation and training of social entrepreneurship in a specific community, the aim of the study was to determine the distinctive psychosocial profiles of each stage and, based on that, to define their basic objectives for psychosocial skill training.

From a training perspective, along with a proper identification of the previously mentioned objectives, it could be valuable to determine how social entrepreneurship and social innovation can be promoted in youth. If we agree that social entrepreneurship can be seen as a stable career path, it is possible to regard the related psychosocial process as some sort of social orientation and, particularly, as an entrepreneurial attitude. In order to do so, a specific theoretical and empirical approached must be adopted.

\subsection{Social Entrepreneurship as Planned Behavior}

The main trend in the study of entrepreneurial intention is Ajzen's Theory of Planned Behavior (TPB), which has been validated as the main theoretical background to understand entrepreneurial intention at an individual level (Liñán \& Fayolle, 2015). Furthermore, some studies establish the relationship between entrepreneurship education and intention, providing evidence about the positive impact of formal training on entrepreneurship intention. As Liñán and Fayolle (2015) summarized, three main conclusions have been reached regarding entrepreneurial training programs: a) students that participated in such programs developed higher attitudes and intentions; b) the methodologies and contents are specific to the programs; and c) it is necessary to improve research methodologies to evaluate them. Further evidence regarding entrepreneurial attitude can be found in Liñán and Fayolle 2015; Moriano, Palací, \& Morales, 2007; and Sánchez 2010.

As for the TPB as the reference theory when studying entrepreneurial attitude an intention (Krueger, Reilly and Carsrud 2000; Moriano 2005; Liñán and Chen, 2009; Moriano, Gorgievski, Laguna, \& Zarafshani 2012), it also constitutes a strongly validated theory in Social Psychology since it focuses on the interaction between personal and social aspects in order to explain some behaviors (Fayolle, Liñán, \& Moriano, 2014). This theory can also integrate, in a broader framework, research on attitudes and self-efficacy (Liñán \& Fayolle, 2015). In general terms, the TPB proposes that a specific behavior intention can be explained by the presence of three elements: a) attitude towards behavior, understood as beliefs about the behavior and their importance (Ajzen, 1991); b) subjective norm, i.e. normative beliefs and motivation to comply with these beliefs regarding their attributed importance (Ajzen 1991); and c) perceived behavioral control, defined as personal beliefs about the individuals' own ability to perform the behavior successfully, similar to self-efficacy (Fayolle et al. 2014). In the specific case of university students, Gird and Bagraim (2008) stated that the TPB is a fully sufficient explanation of entrepreneurship intentions, and that situational factors or personality traits can influence some of the variables of the TPB, but without direct effects on entrepreneurial intentions. Yang (2013) reached a similar conclusion in a study with a sample of 1,330 Chinese undergraduate students, indicating that 
attitude is the main predictor of entrepreneurial intention, followed by subjective norm and perceived behavioral control.

The application of the TPB to the study of social entrepreneurship is recent, but completely adequate. To generate an entrepreneurial project that includes social or environmental impact, planning and cognitive processes are required; therefore, social entrepreneurship can be understood as a planned behavior and studied from the behavior intention models. Liñán and Fayolle's (2015) literature review includes seven articles related to social entrepreneurship as a planned behavior, and four regarding sustainable entrepreneurship intentions. The authors highlight the emerging nature of this topic of research, and put forward that the TPB model can be successfully applied to the study of social entrepreneurship. Two studies were conducted with undergraduate students, both carrying some implications for the training process. In the first one, Prieto (2011) found a strong relationship between proactive personality and social entrepreneurship intentions. In the second one, Prieto, Phipps and Friedrich (2012) concluded that 30\% of Afro-American and Hispanic undergraduate students had a high social entrepreneurship intention, and proposed a model to develop social entrepreneurial behavior based on the TPB.

\subsection{Traditional and Social Entrepreneurial Training.}

A number of initial studies have been published on the interaction among aspects of the TPB and the entrepreneurial learning behavior. Chou, Shen and Hsiao (2011) found some interesting associations: high entrepreneurial self-efficacy predicted higher entrepreneurial intentions and, in turn, entrepreneurial intention had a direct effect on entrepreneurial learning behavior. Therefore, the development of higher entrepreneurial attitude, self-efficacy and intention can facilitate the entrepreneurship learning process in formal situations. Such findings are vital to the study in hand as it considers several stages of training and that attitudes formed in the first levels can play a role in the latter. Prieto et al. (2012) proposed that attitude and perceived behavioral control related to social entrepreneurship intentions must be assessed at different stages to challenge students by non-traditional methodologies (West, Tateishi, Wright, \& Fonoimoana, 2012) and an enriching network of mentors. Regarding general entrepreneurial intentions, other investigations also indicated that the training process should include activities to develop positive attitudes and to generate positive experiences of entrepreneurship (Gird and Bagraim, 2008; Yang, 2013).

Even though social entrepreneurship is a new research and education area, the growing body of evidence sufficiently supports the need to include main activities in these programs in order to develop a positive attitude towards social entrepreneurship and high self-efficacy. García, Moriano and Palací (2003) proposed an entrepreneurial training model based on a competency model which focuses on a) encouraging realistic and positive attitudes towards entrepreneurship; b) developing entrepreneurship self-efficacy; and c) increasing proactivity and goal orientation.

A look to other variables can provide further evidence related to the use of the TPB in the study of the entrepreneurship training process from a psychosocial point of view. In the first place, values and motives behind entrepreneurial intentions can be a focus of interest. Fayolle et al. (2014) pointed out that, despite the lack of empirical evidence, values can play a role in attitude formation and motives can participate in the activation of the intention-action link. In this respect, there is some evidence of the relationship among individualistic values and entrepreneurial intentions and behaviors (Hayton, George and Zahra 2002; Fayolle et al., 2014). While further research about the interplay between personal and cultural values is needed, there is theoretical clarity about the importance of both factors in entrepreneurial intentions. Other variables that are being taken into consideration are gender, economic, demographic and social factors.

Regarding gender and social entrepreneurship training, a study about gender differences in desirability, feasibility, intention, and social image of entrepreneurship among undergraduate students involved in a business creation program $(n=400)$, revealed that male participants had higher intention and also evaluated the social image of entrepreneurs more positively (Sánchez-Escobedo, Díaz-Casero, HernándezMogollón, \& Postigo-Jimenez, 2011). Similarly, a study with Malayan undergraduate students (n=318) revealed that, while there was no evidence of differences in entrepreneurial intentions according to race, field of study, work experience or parents' occupation, male participants scored, again, higher than female participants in entrepreneurial intention (Rasli, Rehman, Malekifar, \& Jabeen, 2013). 
As for social entrepreneurship, there is some evidence concerning psychosocial variables related to social entrepreneurs, such as social motives, higher values of benevolence and universalism, lower values of conformism and tradition, higher perspective taking empathy, higher autonomy and change orientation, and higher internal locus of control compared to traditional entrepreneurs, volunteers and philanthropist $(n=96)$ (Bargsted et al. 2013). Also, according to Barendsen and Gardner (2004), social entrepreneurs are more proactive when learning new abilities and able to take personal and work risk, they are innovative and try to integrate social orientation into their career, and they are self-confident and feel comfortable with diversity.

The results of the aforementioned works raise the question about which psychosocial variables and attitudes characterize social entrepreneurs at different stages of development of the entrepreneurial competencies. Answering that would allow us to establish clear and effective learning goals in formative programs. Ergo, in order to study and determine such goals, two main hypotheses were formulated:

H1: It is possible to identify specific psychosocial characteristics related to each step of social entrepreneurship training.

a. Participants in earlier stages will present more conservative and self- oriented values and intentions to help.

b. Participants in earlier stages will have a lower positive social entrepreneurship attittude.

c. Participants in earlier stages will present lower social entrepreneurship self-efficacy beliefs.

H2: Even if it is possible to find different predictors of social entrepreneurship intention, the main predictor will be social entrepreneurship attitude.

\section{Method}

The study was conducted using an ex post facto factorial research design, with three groups structured according to different stages in social entrepreneurship development. In the community of Antofagasta, Chile, three formal programs oriented to develop social entrepreneurship were identified:

a) Youth social leadership program developed by a local NGO targeting high school students (15 -18 years old) from different schools $(n=38)$

b) Undergraduate course of social entrepreneurship oriented to college students (18 to 25 years old) of different faculties and universities of the city $(n=48)$

c) Local funding contest of social innovation promoted by a local NGO oriented to social entrepreneurs (23 to 41 years old) with specific projects $(n=51)$

Based on that, three different development phases of social entrepreneurship were defined: a) stage 1: discovery and initial trainning; b) stage 2: formal trainning and first project; and c) stage 3: planning and implementation of social entrepreneurship projects.

All participants were contacted by public, private and non-governmental organizations oriented to support entrepreneurship, and invited to answer an on-paper $(46 \%)$ or on-line questionnaire. $52 \%$ of the participants were men. All participant that answered the questionnaire $(n=137)$ were volunteers and were informed about the aims of the research. The questionnaire was structured in six sections:

- Personal values were measured using the Escala de Valores en el Trabajo (EVAT), a work values scale consisting in a Spanish version of the Schwartz survey which provides information about the centrality of ten motivational types based on values. This instrument was previously applied to the study of the Chilean working population (Bargsted, 2008) and of social entrepreneurs (Bargsted et al. 2013), obtaining adequate psychometric properties. The EVAT consists of 30 items rated on a 6-point Likert scale $(1=$ "Not like me at all" and $6=$ "Very much like me"). In the present study, reliability was 0.86

- Proactivity, risk propensity, and locus of control were measured with the Entrepreneurial Orientation Questionnaire (Sanchez, 2010), constructed and validated for the Spanish speaking population by the CFA with an internal consistency of 0.77 . The inventory has 23 items rated in a 6-point Likert scale (1 = "Totally desagree", $6=$ "Totally agree").

- Motivation to helping behavior was measured with an instrument developed for the Spanish speaking population by Ménard, Vecina, Chacón and Sanz (1997) consisting of 30 items in a 7-point Likert scale $(0=$ "Not Important to me", 6 = "Very Important to me"). This scale allows to identify the orientation to help based on principles and community consideration (both altruistic motives), as well 
as on kwoledge, improve self-steem, and personal development (egoistic motives). It has an internal consistency of 0.91 .

- Social entrepreneurship attitudes relative to the TBP were measured with the SEIQ, a scale developed by the UNED (Spain) in validation process by the authors and based on a scale similar to the one used for traditional entrepreneurship (Moriano, 2005). The SEIQ includes three scales to measure a) attitudes towards social entrepreneurship (positive beliefs and relative importance of these) with 9 items rated in a 7-point scale ( $0=$ "Very undesirable", $6=$ "Very desirable") and an internal consistency of 0.91 ; b) subjetive norm as the perception and importance of support from family, friends and collegues, with 6 items rated in a 7 -point scale $(0=$ "Totally desagree", $6=$ "Totally agree") and an internal consistency of 0.78 , and c) social entrepreneurship self-efficacy was measured using 12 items rated in a 7 -point scale $(0=$ "No confident at all", $6=$ "Totally confident") and a reliability of 0.92 .

- Social entrepreneurship intention was measured according to five items other than the ones included in the SEIQ. These five items are oriented to measure the explicit intentions to engage in projects with social impact.

- Demographic variables included years of education of the participant and their parents, profession and entrepreneurial experience of the participants and their parents, age, gender and perceived socioeconomic status.

All the data were analyzed using comparative statistical techniques and regression analysis to evaluate the prediction of social entrepreneurship intentions according the TPB.

\section{Results}

In order to describe each group and their particular psychosocial profile, several statistical analyses were conducted to establish the most significant differences among them. A Chi ${ }^{2}$ test was used to compare categorical variables (e.g. gender and socio economic classification), and a one-way Anova analysis was used for each item according to their numerical values (beliefs, attitudes, motives and social entrepreneurship intentions). The results are presented below.

\subsection{Demographic Aspects}

There was a significantly higher proportion of women in Stage $1(55 \%)$ and Stage $2(60 \%)$ compared to Stage $3(28 \%)$. The effect size of this difference is medium $\left(\mathrm{Chi}^{2}=11.751, \mathrm{gl}=2, \mathrm{p}=0.003, \omega=0.33\right)$. It is complex to determine whether this effect size derives from a sampling error (as sampling was voluntary among participants of the three stages) or from the lower female proportion in Stage 3 , related to developing projects. If the said differences are indeed caused by a lower female proportion in Stage 3 , it will be necessary to study in depth the existence of possible gender barriers in the implementation stage.

\subsection{Psychosocial Profiles}

Several differences among groups were detected. Table 1 provides a list of all items in which the Anova analysis found significant differences among groups. Furthermore, the t-test between groups is also reported.

Specifically, differences in four of the ten values were identified. On the one hand, participants of Stage 1 had higher scores in values of Tradition and Society Stability than participants of Stages 2 and 3, which provides valuable information about a key aspect to be developed in order to encourage innovation and change. Also, they were less oriented to Universalism values, expressed through their awareness of collective well-being, equity, and self-transcendence. On the other hand, participants of Stage 3 were less oriented to pleasure, maybe due to a higher orientation to specific and objective efforts to their projects instead. These findings lead us to reflect on the ludic aspects of the innovation training methodologies and their equilibrium with reality orientation. Finally, regarding the Achievement value, it was higher for participants of Stage 2 as compared to those of Stage 3. Further research on this value should be conducted since previous works report its linkage with entrepreneurship intentions (as it was discussed in the introduction). 


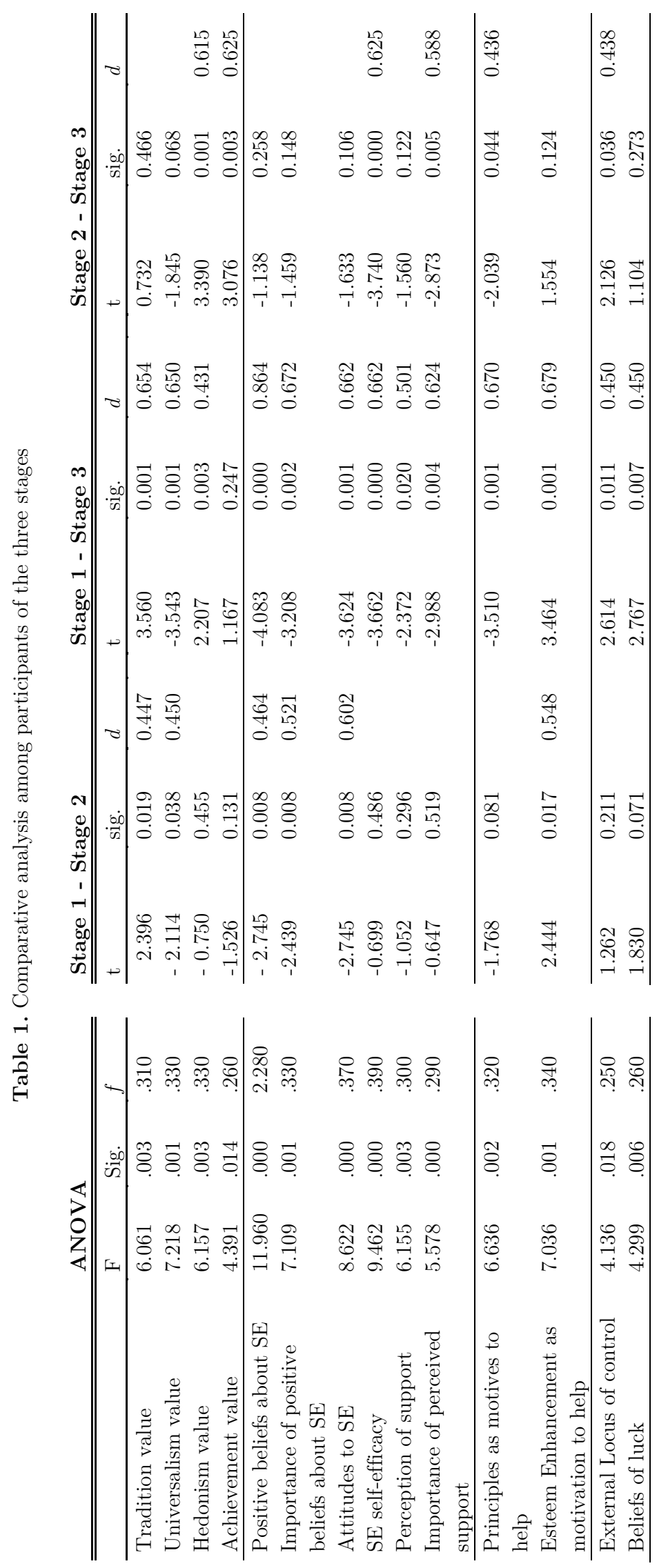


According to the above-mentioned results, Hypothesis 1a is not rejected, since participants of Stage 1 presented higher scores in the Tradition value and lower ones in the Universalism value, as opposed to participants of Stage 3. With respect to their motives to help, Stage 1 participants oriented their helping behavior as a way to improve their self-esteem, whereas Stage 3 participants were more guided by their principles, as hypothesized in 1a. Therefore, the development of empathy from a self-centered perspective to a hetero-centered one must be included as a specific training goal.

Regarding positive attitudes towards social entrepreneurship, participants of Stage 1 showed lower scores compared to participants of the upper stages and, in turn, participants of Stage 2 had lower positive attitudes than those of Stage 3. Moreover, at the last stage, participants had more positive beliefs about social entrepreneurial self-efficacy connected to their experiences, and they also perceived more support (subjective norms). These findings support Hypotheses 1b and 1c. A practical implication of this conclusion can be translated into the promotion and inclusion of activities aimed at developing positive attitudes towards social entrepreneurship at stage 1, and self-efficacy and more perceived support at Stage 2. Finally, participants of Stage 3 were less oriented to externalize locus of control and believe in luck, which offers an interesting training goal for the first and second stages.

\subsection{Social Entrepreneurship Intention Prediction}

Multiple regression analyses were performed to establish which variables are useful to predict social entrepreneurship intention for each group. The most relevant model corresponds to Stage 3, due to the fact that its participants are already developing social entrepreneurship projects. These analyses were performed twice per group: once including all the variables as predictors, and a second time using the TBP variables. Table 2 shows the results of the first models per group.

Table 2. Regression Models of SE intention for each group using all variables as predictors

\begin{tabular}{lllllll}
\hline Stage & $\mathrm{R}$ & $\mathrm{R}^{2}$ & $\mathrm{R}^{2}$ adjusted & Standard Error & Durbin-Watson & Effect size $f^{2}$ \\
\hline 1 & 0.984 & 0.968 & 0.952 & 0.233 & 2.064 & 25.31 \\
2 & 0.639 & 0.408 & 0.359 & 0.523 & 1.788 & 0.68 \\
3 & 0.568 & 0.322 & 0.292 & 0.727 & 1.815 & 0.47 \\
\hline
\end{tabular}

For Stage 1, the model identified is robust and includes the following variables as predictors: positive attitudes towards social entrepreneurship, external locus of control, motive to help related to personal development, beliefs in luck (inverse) and conformity value (inverse). These results highlight two main issues to be addressed: selection and training processes. As it will be discussed later, we must stress that, should a selection criterion be necessary, the external locus of control (typical of this age) should not be included. With respect to the training process, it seems that developing a more change oriented values profile would be a key aspect at the first stage.

For Stage 2, the model is still significant and has a high effect size, although it includes fewer variables. Specifically, social entrepreneurship intention at this stage can be predicted, according to the scores of positive attitudes towards social entrepreneurship, lower conformity value, and lower orientation to help induced by self-esteem enhancement.

And for Stage 3, the results show that only positive beliefs and attitudes towards social entrepreneurship can predict social entrepreneurship intentions, to the extent that there was a homogeneous group in the variables of higher internal locus of control, motives to help connected to altruism, and lower values of conformity and tradition. This means that, once social entrepreneurship trainees have developed a similar psychosocial profile, their attitude becomes fundamental to engaging in social entrepreneurship projects.

Finally, path analyses were used in order to evaluate a predicted model of TPB for each group. For the first stage, r2 was 0.58, and betas of all variables were positive, with attitudes towards social entrepreneurship as the highest. Conclusively, all the TPB variables can predict the social entrepreneurship intention in a significant extent $\left(f^{2}=1.38 ; 1-\beta>0.99\right)$. 


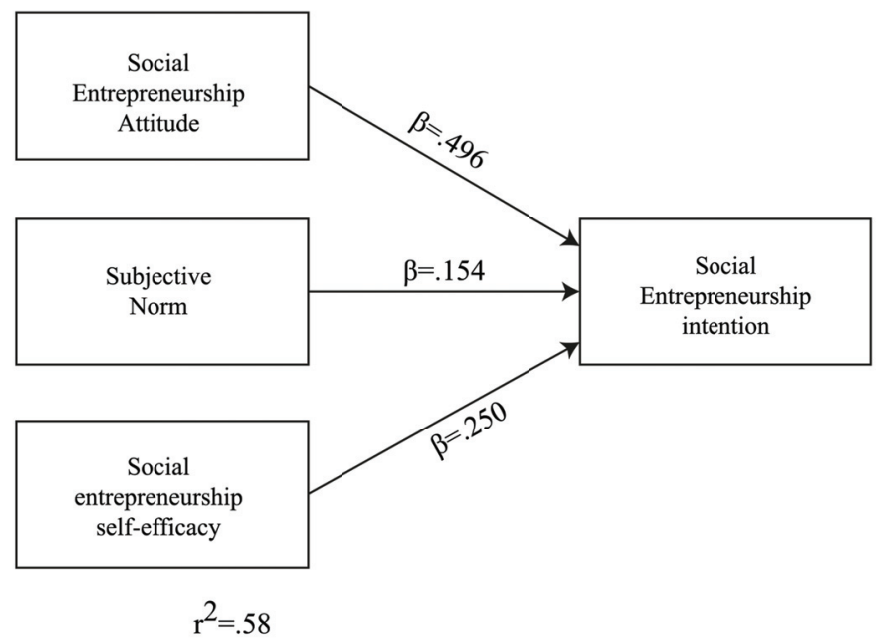

Figure 1. Prediction model of social entrepreneurship intention for stage 1.

For both Stage 2 and 3, only positive attitudes towards social entrepreneurship had a main role in the prediction of social entrepreneurship intentions. Please, note that if other TPB variables were included in the model, their regression weights would be lower. Furthermore, in Stage 2, $\mathrm{r}^{2}$ of the model was small, (see Figure 2). This model has a medium size effect $\left(f^{2}=0.162\right)$, but not enough power $(1-\beta<0.8)$, so it cannot predict social entrepreneurship at Stage 2 properly. A larger group would be necessary so as to maintain the prediction power of the model.

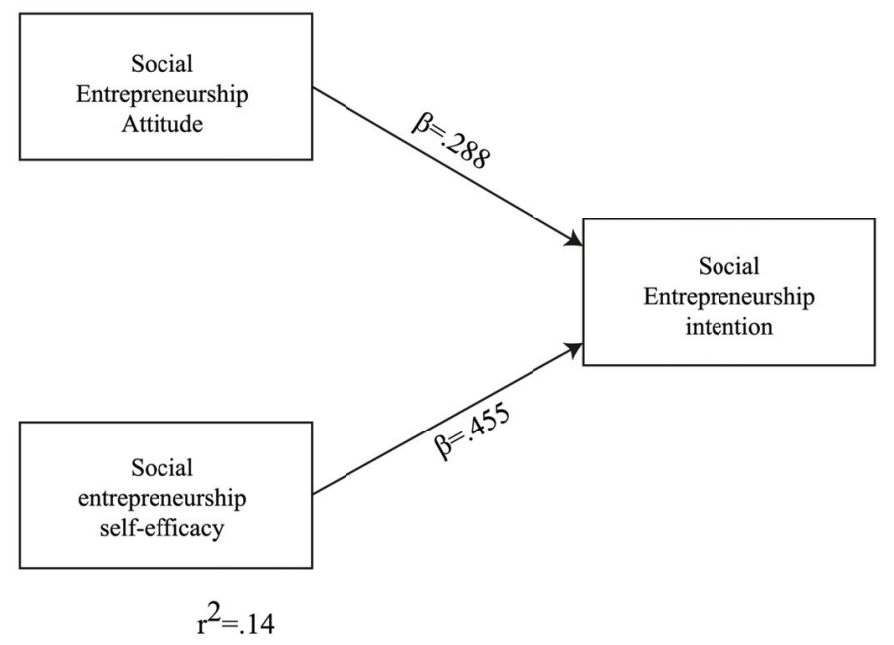

Figure 2. Prediction model of social entrepreneurship intention for stage 2.

Finally, for Stage 3, the prediction power of the model was higher, and the effect size was adequate $(f=0.35,1-\beta=0.94)$, but only for the effect of attitudes towards social entrepreneurship as predictor.

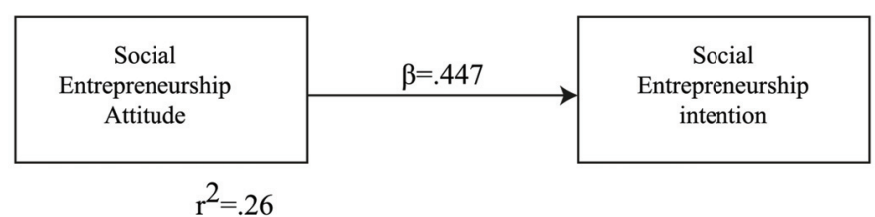

Figure 3. Prediction model of social entrepreneurship intention for stage 3 . 
As expected, attitude was the main predictor $(\mathrm{H} 2)$, yet stages 1 and 2 also included other significant predictors, like conformity value, egoistic motives to help, and external locus of control (all in inverse way). Moreover, it is plausible that, as social entrepreneurs advance in their training, values and motives to help can change and, consequently, a positive attitude towards social entrepreneurship can be developed.

\section{Conclusion}

Social entrepreneurship and, specifically, social entrepreneurship and innovation training programs are new areas of research and development in the field of entrepreneurship. As an emerging subject, there are several questions still without answer (Liñán \& Fayolle, 2015). The aim of this study was to explore the relationship among several psychosocial characteristics and social entrepreneurship intention in three specific training programs oriented to different stages of social entrepreneurship and innovation. As expounded in the results section, specific psychosocial characteristics for each studied group were identified, which can help to design goals and tasks for each training program. This characterization of the social entrepreneur profile at different training stages validates the significant relevance of developing competencies and attitudes associated to social entrepreneurship intentions (Vasakarla, 2008), in the framework of the aforementioned theories about entrepreneurship and innovation prediction and education (Liñan, 2007). Furthermore, the results yielded by this research can contribute to the design of training and coaching programs for social entrepreneurs, who may have to tackle several difficulties and challenges in order to develop innovative and non-traditional entrepreneurship career paths. The results also allowed to visualize the need of focusing on relevant goals at a fourth stage of the social entrepreneurship process, i.e. studying psychosocial profiles of social entrepreneurs that can maintain their projects through time, and developing counseling and mentoring programs to enhance the probability of success over time.

Based on the analysis of the data and the resulting characterization of the groups participating at each of the training stages, the main training objectives to be achieved by social entrepreneurship trainees are proposed (see Table 3).

Table 3. Group characterization and training goal proposed

\begin{tabular}{lll}
\hline Stage & Characterization & Main goals (developing areas) \\
\hline $\mathbf{1}$ & $55 \%$ women & Hetero-centered empathy (perspective taking) \\
& Highest in Tradition value & Change orientation in values \\
& Lowest in Universalism value & Internal locus of control \\
& Self- esteem enhancement as a main motive to help. & Positive attitudes towards social entrepreneurship \\
& Highest external locus of control and beliefs of luck & \\
\hline $\mathbf{2}$ & $60 \%$ women & Perception of effective social support \\
& Highest in Achievement value & Persistence \\
& Lowest in Tradition value & Orientation to specific groups in need \\
& Higher positive attitudes towards social & Change Orientation \\
& entrepreneurship & Further strengthening of positive attitudes \\
& towards social entrepreneurship, internal locus of \\
& control, and hetero-centered empathy \\
\hline $\mathbf{3}$ & Give special attention to women participation \\
& Highest in Universalism value & and barriers \\
Lowest in Hedonism value & Stimulate energy and persistence \\
Principles as main motive to help. & Maintain attitudes, beliefs about social support \\
Lowest external locus of control and beliefs of luck & and self-efficacy beliefs \\
Most favorable attitudes towards social & \\
entrepreneurship & \\
Highest level of self-efficacy beliefs & \\
Highest perception of social support & \\
&
\end{tabular}


Finally, the following lines highlight some further applications of this research and put forward possible future lines of research in relation to social entrepreneurship and s training. The results of this study can provide answers to some of the concerns expressed by designers and sponsors of social entrepreneurship programs. First, it is common to hear questions about whether to do a selection process or not. As we can see, profiles of the first two stages were diverse and there is no evidence about dispositional characteristics that improve, by themselves, the probability to become an entrepreneur (Rauch \& Frese, 2007). Furthermore, in this research, several psychosocial characteristics were examined as potential precursors of social entrepreneurship intentions, all of which can be developed. Therefore, it is recommendable to conduct a pre-evaluation, but not to select participants according to its assessment, as Fayolle and Degeorge (2006) proposed.

Rather than setting out selection criteria, the results of this study suggest three main training areas which can stimulate trainees' social entrepreneurship intention: a) developing hetero-centered empathy (perspective taking empathy) from a knowledge and understanding of others' reality; b) stimulating a more proactive orientation towards social change (increasing nonconformity, the need of pushing themselves further, and the values of self-transcendence and self-direction); and c) stimulating positive attitudes and beliefs towards social entrepreneurship, social support, and their own skills to become a change maker (Veciana, Aponte, \& Urbano, 2005).

And second, once training and intervention (at the three stages) are finished, it is fundamental to follow up each group and their transition between stages. Such a measure implies assessing students' entry and exit profiles at each stage, as well as their progression to a following stage, if any. Table 3 constitutes a useful tool to establish the initial and final competency profiles.

Regarding gender, further analysis of the causes of the observed lower proportion of women at Stage 3 is necessary, in order to identify any entry or permanent barriers to female social entrepreneurs at the implementation stages. Plausible explanations to this phenomenon are: self-exclusion process, bias in financial evaluation or even prejudice and discrimination in funding contests or investor's evaluations. Moreover, a study on the nature and characteristics of male and female social entrepreneurship projects could provide interesting results regarding their differences, if any.

Finally, the methodology used in this study can be extended to the analysis of the characteristics of social entrepreneurs with on-going projects showing impact and good results, in order to complete the profiles at the maintaining stage. Even though social entrepreneurship initiatives improve the quality of life of our society in a permanent way, they face several difficulties to remain sustainable. Information about the psychosocial profiles of consolidated social entrepreneurs would be useful to help new social innovative entrepreneurship projects to last in time.

Acknowledgments. The author would like to acknowledge the Minera Escondida Foundation (Chile) for financial support and facilities to contact participants.

\section{References}

1. Ajzen, I. (1991). Theory of planned behavior. Organizational behavior and human decision processes, 50, 179211.

2. Arnold, J. (2001). Careers and career management. In N. E. Anderson, Handbook of Industrial, Work adn organizational psychology (Vol. 2). Sage Publications.

3. Bacq, S., \& Janssen, F. (2011). The multiple faces of social entrepreneurship: A review of definitional issues based on geographical and thematic criteria. Entrepreneurship $\&$ Regional Development: An International Review, 23(5-6), 373-403. doi: DOI:10.1080/0895626.2011.577242

4. Barendsen, L., \& Gardner, H. (2004). is the social entrepreneur a new type of leader? Leader to leader, Fall, 4350.

5. Bargsted, M. (2008). Éxito integral en la carrera laboral: congruencia entre valores y metas. Tesis para optar al grado de Doctor en Psicología por la Universidad Autónoma de Madrid. Madrid, España.

6. Bargsted, M., Picón, M., Salazar, A., \& Rojas, Y. (2013). Psychosocial characterization of social entrepreneurs: a comparative study. Journal of social entrepreneurship, 4(3), 331-346. doi:10.1080/19420676.2013.820780 
7. Chou, C.-M., Shen, C.-H., \& Hsiao, H.-C. (2011). The influence of entrepreneurial self-efficacy on entrepreneurial learning behavior - using entrepreneurial intention as the mediator variable. International Business and Management, 3(2), 7-11. doi:10.3968/j.ibm.1923842820110302.4Z0145

8. Dacin, P. A., Dancin, M. T., \& Matear, M. (2010). Social Entrpreneurship: why we don't need a new theory and how we move foward from here. Academy of management perspective, August, 37-57.

9. Fayolle, A., \& Degeorge, J. M. (2006). Attitudes, intentions and behaviour: New approaches to evaluating entrepreneurship education. In A. Fayolle, \& H. Klandt, International Entrepreneurship Education. Issues and Newness (págs. 74-92). Cheltenham, UK: Edward Elgar.

10. Fayolle, A., Liñán, F., \& Moriano, J. A. (2014). Beyond entrepreneurial intentions: values and motivations in entrepreneurship. International entrepeneurship management journal, 10, 679-698. doi:10.1007/s11365-014-03067

11. García, P. A., Moriano, J. A., \& Palací, F. (2003). Un modelo de formación para el autoempleo en Europa. In M. L. Sánchez, J. A. Moriano, \& C. Sevilla, Guía Luces para emprendedores (págs. 17-38). Cáceres: Patronato Pedro de Ibarra.

12. Gird, A., \& Bagraim, J. (2008). The theory of planned behavior as predictor of entrepreneurial intent amongst final-year university students. South african journal of psychology, 38(4), 711-724. doi: $10.1177 / 008124630803800410$

13. Greenhaus, J., Callanan, G., \& Godshalk, V. (2010). Career Management. California: Sage Publications.

14. Hayton, J., George, G., \& Zahra, S. (2002). National culture and entrepreneurship: a review of behavioral research. Entrepreneurship: theory and practice, 26(4), 33-52.

15. Krueger, N., Reilly, M., \& Carsrud, A. (2000). Competing models of entrepreneurial intentions. Journal of Business Venturing, 15, 411-432.

16. Liñán, F. (2007). The role of entrepreneurship education in the entrepreneurship process. En A. Fayolle, Handbook of research in entrepreneurial education. Cheltenham, UK: Edward Elgar.

17. Liñán, F., \& Chen, Y. (2009). Development adn cross-cultural application of a specific instrument to measure entrepreneurial intentios. Entrepreneurship Theory and Practice, 3(3), 593-617.

18. Liñán, F., \& Fayolle, A. (2015). A systematic literature review on entrepreneurial intentions: citation, thematic analyses, and research agenda. International Entrepreneurship Management Journal. doi:10.1007/s11365-0150356-5

19. Mair, J., \& Martí, I. (2006). Social entrepreneurship research: a source of explanation, prediction and delight. Journal of World Business, 41, 36-44.

20. Ménard, M., Vecina, M., Chacón, F., \& Sanz, M. (1997). Factores Psicosociales que influyen en el voluntariado: Un estudio Piloto. Intervención Psicosocial: revista sobre igualdad y calidad de vida, 61(1), 105-116.

21. Moriano, J. A. (2005). El perfil psicosocial del emprendedor. Madrid: Consejo Económico y Social.

22. Moriano, J. A., Gorgievski, M., Laguna, M. S., \& Zarafshani, K. (2012). A Cross-cultural approach to understanding entrepreneurial intention. Journal of career development, 39, 162-185. doi: $10.1177 / 0894845310384481$

23. Moriano, J. A., Palací, F., \& Morales, J. F. (2007). The Psychosocial profile of the university entrepreneur. Psychology in Spain, 11, 72-84.

24. Prieto, L. (2011). The influence of proactive personality on social entrepreneurial intentions among africanamerican and hispanic undergraduate students: the moderating role of hope. Academy of Entrepreneurship Journal, $17(2), 77-96$.

25. Prieto, L., Phipps, S., \& Friedrich, T. (2012). Social Entrepreneur development: an integration of critical pedagogy, the theory of planned behavior and the ACS model. Academy of Entrepreneurship Journal, 18(2), 115.

26. Rasli, A., Rehman, S., Malekifar, S., \& Jabeen, S. (2013). Factors affecting entrepreneurial intention among graduate students of university teknologi Malaysia. International Journal of Businnes and Social Science, 4(2), 182-188.

27. Rauch, A., \& Frese, M. (2007). Born to be an entrepreneur? Revisiting the personality approach to entrepreneurship. In J. Baum, M. Frese, \& R. A. Baron, The psychology of entrepreneurship. The organizational frontiers (pp. 41-65). Mahwah, NJ, US: Lawrence Erlbaum Associates Publishers.

28. Sánchez, J. C. (2010). Evaluación de la personalidad emprendedora : validez factorial del cuestionario de orientación emprendedora COE. Revista latinoamericana de Psicología, 42(1), 41-52. 
29. Sánchez-Escobedo, M. d., Díaz-Casero, J. C., Hernández-Mogollón, R., \& Postigo-Jimenez, M. V. (2011). Perceptions and attitudes toward entrepreneurship. An Analysis of gender among university students. International Entrepreneurhip Management Journal, 7, 443-463. doi:10.1007/s/11365-011-0200-5

30. Schein, E. (1996). Career anchors revisited: implications for careers in the 21st century. Academy of management Executive, 10, 80-88.

31. Vasakarla, V. (2008). A study on social entrepreneurship an the characteristics of social entepreneurs. Journal of Management Research, 7, 32-40.

32. Veciana, J., Aponte, M., \& Urbano, D. (2005). University students' attitude toward entrepreneurship: a two countries comparison. The International Entrepreneurshio and Management Journal, 1(2), 165-182.

33. West, R. E., Tateishi, I., Wright, G. A., \& Fonoimoana, M. (2012). Innovation 101: Promoting Undergraduate Innovation Through a Two-Day Boot Camp. Creativity Research Journal, 24(2-3), 243-251. doi:10.1080/10400419.2012.677364

34. Yang, J. (2013). the theory of planned behavior and prediction of entrepreneurial intentios amog chinese undergraduates. Social behavior and personalitu, 41(3), 367-376. doi:10.2224/sbp.2013.41.3.367

35. Zahra, S., Gedajlovic, E., Neubaum, D., \& Shulman, J. (2009). A typology of social entrepreneurs: motives, search processes and ethical challenges. Journal of Business Venturing, 24, 519-532. 